\title{
1 One Hundred and Fifty Years of Warming on Caribbean Coral Reefs
}

2

3 Colleen B. Bove ${ }^{1,2^{\star}}$, Laura Mudge ${ }^{1,3}$, and John F. Bruno ${ }^{1}$

$4{ }^{1}$ The Department of Biology, The University of North Carolina at Chapel Hill, Chapel Hill, North Carolina, 27599-

53280 USA

$6 \quad{ }^{2}$ The Department of Biology, Boston University, Boston, Massachusetts, 02215 USA

$7 \quad$ Integral Consulting Inc., Annapolis, Maryland 21401 USA

$8 \quad{ }^{*}$ Corresponding author: colleenbove@gmail.com 


\section{Abstract}

10 Anthropogenic climate change is rapidly altering the characteristics and dynamics of

11 biological communities. This is especially apparent in marine systems as the world's oceans

12 are warming at an unprecedented rate, causing dramatic changes to coastal marine

13 systems, especially on coral reefs of the Caribbean. We used three complementary ocean

14 temperature databases (HadISST, Pathfinder, and OISST) to quantify change in thermal characteristics of Caribbean coral reefs over the last 150 years (1871-2020). These sea surface temperature (SST) databases included combined in situ and satellite-derived SST

17 (HadISST, OISST), as well as satellite-only observations (Pathfinder) at multiple spatial 18 resolutions. We also compiled a Caribbean coral reef database identifying 5,326 unique reefs across the region. We found that Caribbean reefs have warmed on average by $0.20^{\circ} \mathrm{C}$ per decade since 1987, the calculated year that rapid warming began on Caribbean reefs.

21 Further, geographic variation in warming rates ranged from $0.17^{\circ} \mathrm{C}$ per decade on

22 Bahamian reefs to $0.26{ }^{\circ} \mathrm{C}$ per decade on reefs within the Southern and Eastern Caribbean ecoregions. If this linear rate of warming continues, these already threatened ecosystems

24 would warm by an additional $1.6^{\circ} \mathrm{C}$ on average by 2100 . We also found that marine heatwave (MHW) events are increasing in both frequency and duration across the Caribbean. Caribbean coral reefs now experience on average $5 \mathrm{MHW}$ events annually, compared to 1 per year in the early 1980s. Combined, these changes have caused a dramatic shift in the composition and function of Caribbean coral reef ecosystems. If reefs continue to warm at this rate, we are likely to lose even the remnant Caribbean coral reef communities of today in the coming decades. 


\section{Introduction}

32 Greenhouse gas emissions are warming the planet, intensifying disturbances (e.g., fires and

33 cyclonic storms), and modifying countless other aspects of the environment. This is causing

34 extinctions, altering species composition, and degrading nearly every ecosystem on earth.

35 Although we tend to think of surface warming as a terrestrial phenomenon, the oceans have

36 stored about $93 \%$ of the additional retained heat since $1955^{1,2}$. The impacts of warming on marine communities are widespread, affecting a large range of taxa ${ }^{3}$. Most marine species are ectothermic, so their body temperature matches that of the surrounding seawater.

Therefore, warming increases their metabolism and subsequently their caloric demands, growth rates, behaviors, etc ${ }^{4,5}$. This in turn has widespread effects on species interactions and the structure of marine food webs ${ }^{6}$. Ocean heating has also been linked to disease outbreaks, the loss of foundation species that provide habitat structure (e.g., corals and kelps), reductions in primary production, and many other changes ${ }^{7}$. The recent National Climate Assessment ${ }^{8}$ described the well-documented effects of ocean warming as "ecosystem disruption" and concluded it will "intensify as ocean warming, acidification, deoxygenation, and other aspects of climate change increase."

Warming episodes are driving unprecedented changes in coral reef ecosystem function and biodiversity globally ${ }^{9-11}$. These changes on coral reefs are particularly evident on Caribbean reefs that have already experienced dramatic ecological shifts over the past several decades ${ }^{12,13}$. Increasing SST on coral reefs has been associated with many negative ecological consequences, including coral bleaching ${ }^{14}$, higher disease prevalence ${ }^{15}$, increased mortality ${ }^{16}$, and overall reductions in metabolic processes across marine taxa 17,18. While ocean warming is a global phenomenon, differences in the rate of warming can be highly localized ${ }^{19}$, emphasizing the need to understand the thermal histories of the ecosystems most vulnerable to projected ocean warming. 
59 (HadISST, Pathfinder SST, and OISST) for all mapped coral reef locations across the

60 Greater Caribbean (Figure 1). Numerous previous studies have documented the

61 anthropogenic heating of the ocean generally ${ }^{2,20}$, and of coral reefs in particular ${ }^{19,21}$. Our

62 study builds on this work by focusing on coral reefs of the Greater Caribbean, updating the

63 analysis through 2020 , and by adding an assessment of coral reef marine heatwaves to the

64 standard focus on spatiotemporal trends temperature.

65

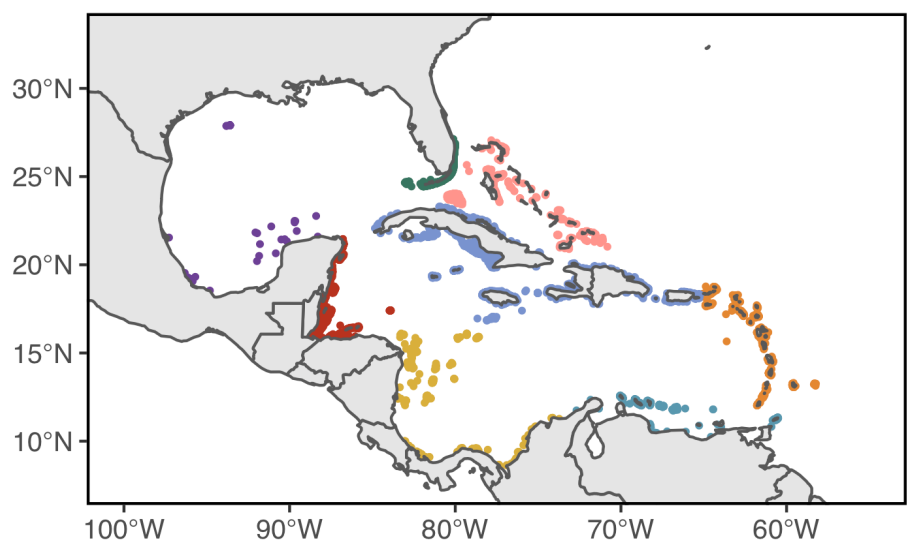

Ecoregion

Bahamian $(n=407)$

Eastern Caribbean $(n=914)$

Floridian $(n=880)$

Greater Antilles $(n=1277)$

- Gulf of Mexico $(n=84)$

Southern Caribbean $(n=367)$

Southwestern Caribbean $(n=365)$

Western Caribbean $(n=1032)$

67 Figure 1. Caribbean coral reef site locations and ecoregion designation. The colour of each reef represents the designated ecoregion and $n$ denotes the number of unique reef locations within that ecoregion.

\section{Results and Discussion}

72 Our results indicate that Caribbean coral reefs continue to warm and that warming over the

73 last 150 years was apparent every month (Figure 2A). In fact, recent spring temperatures often meet or exceed annual highs (typically in September) observed in the late 19th century. Caribbean reef surface temperatures were relatively stable in the mid 20th century

76 (due to volcanic activity ${ }^{22}$ ), then warming increased around 1987 (Figures 2B;

77 Supplementary Figure 1). This timing is similar to long-term records of global ocean surface temperature and ocean heat content ${ }^{23}$ (Figure 2B). We found that the average 
79 linear warming rate for the Caribbean reefs over the last 30 years (1987-2020; HadISST

80 database) was $0.16{ }^{\circ} \mathrm{C}$ per decade (Figure 2; Table 1). Based on satellite data alone

81 (Supplementary Figures 2 and 3; Pathfinder database), the average coral reef warming

82 rate during this period was $0.20^{\circ} \mathrm{C}$ per decade (Table 1). At this rate, the mean temperature

83 on Caribbean reefs would be roughly $1.6^{\circ} \mathrm{C}$ higher by 2100 assuming continued linear

84 warming — and that is in addition to already realized warming.

85

A HadISST $(1871-2020)$

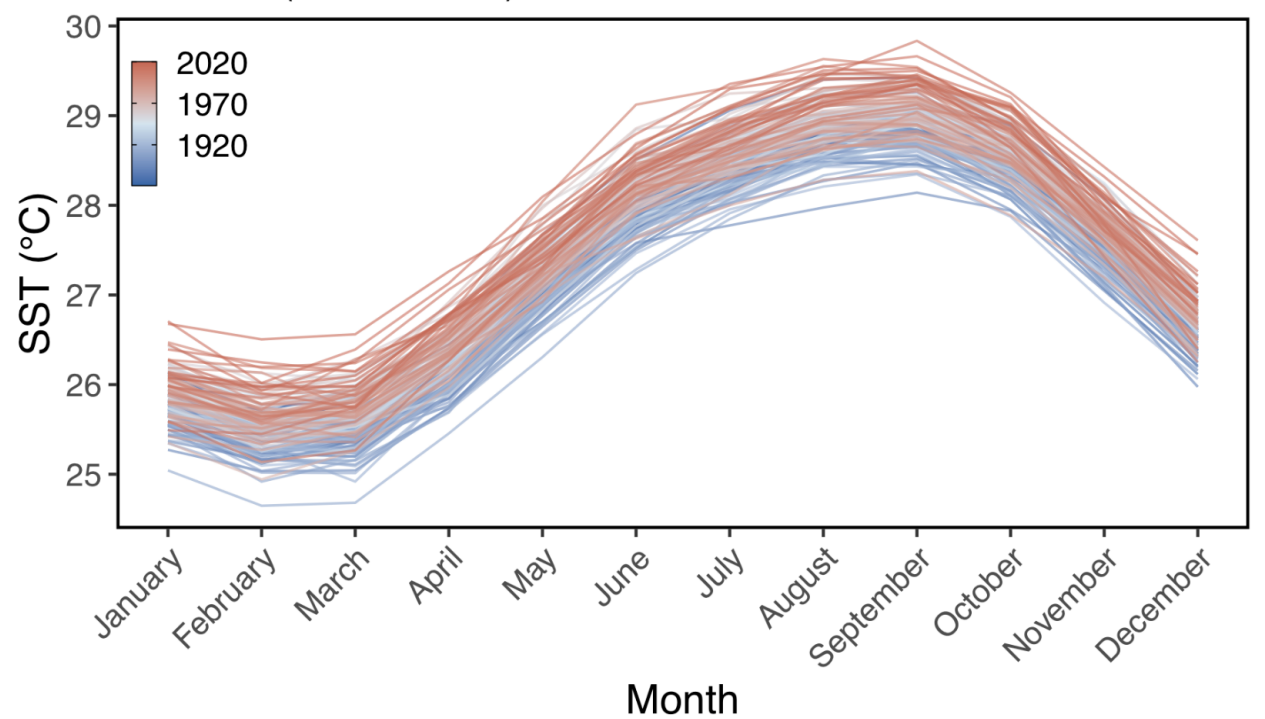

B

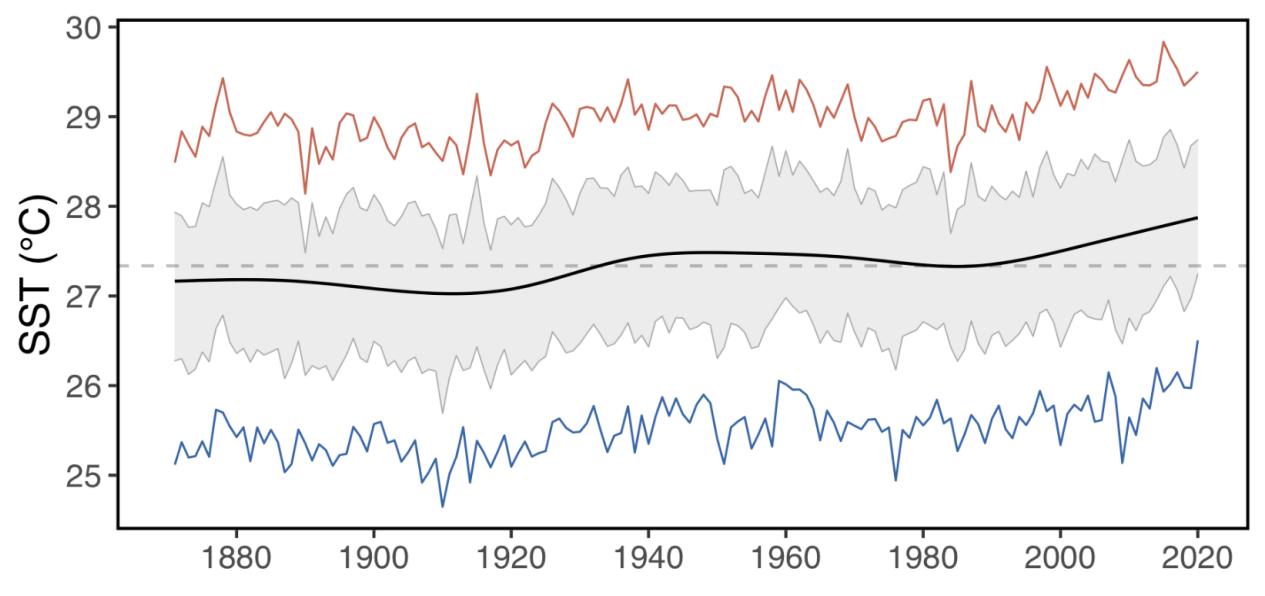

87 Figure 2. Historic SST trend on Caribbean coral reefs (1871-2020). Long-term SST

88 records (HadISST) on Caribbean coral reefs depicting A) mean monthly SST each year 
89 (represented by line colour: blue to red) and B) GAM smoothed annual mean SST time

90 (black line), annual maximum (red line), and annual minimum (blue line) SST. The grey

91 dashed horizontal line denotes the overall mean SST for all sites over the entire period (27.3

${ }^{\circ} \mathrm{C}$ ) and the grey ribbon represents the $95 \%$ confidence interval around the annual mean

93 SST through time.

The observed warming rates of Caribbean coral reefs in this and previous studies report similar values, however, these rates are somewhat greater than estimates for the global ocean surface (Table 2). Winter et al. ${ }^{21}$ reported a warming rate of about $0.25{ }^{\circ} \mathrm{C}$ per decade for the reef off La Parguera, southwestern Puerto Rico (1966-1995). Similarly, Hoegh-Guldberg ${ }^{24}$ found the warming rate was $0.23^{\circ} \mathrm{C}$ per decade (1981-1999) off the south coast of Jamaica. Kuffner et al. ${ }^{25}$ described a remarkable temperature record collected by lighthouse keepers for five coral reefs off the Florida Keys starting in 1878 that also observed SST warming at $0.25^{\circ} \mathrm{C}$ per decade between 1975 and 2006 . It is reassuring

103 (if surprising) that studies of vastly different scales and based on disparate methods,

104 including in situ measurements (e.g., filling a bucket with seawater then measuring

105 temperature by hand with a thermometer ${ }^{21}$, remote sensing via satellite ${ }^{19}$, and databases

106 based on both (this study) report similar warming rates. Moreover, Caribbean reef warming

107 rates are approaching the CMIP5 RCP 8.5 model prediction of about $0.3^{\circ} \mathrm{C}$ per decade ${ }^{26}$.

108 This "business as usual" emissions model is now viewed by many climate scientists as

109 "unlikely", especially for the end of this century. Yet, our results and previous work suggest

110 that Caribbean coral reefs are already warming far more quickly than scenarios considered

111 more likely (e.g., RCP 4.5).

We compared long-term coral reef temperature trends among eight previously-

113 defined ecoregions within the Caribbean ${ }^{27}$. Our results indicate that reefs within all ecoregions have clearly warmed since 1871 (Figures 3; Supplementary Figure 4), albeit at somewhat different rates. Our inflection point analysis determined that the initial year of rapid 
116 warming also varied among ecoregions. For example, rapid warming was identified in the

117 Gulf of Mexico and Southern Caribbean starting in 1981, while rapid warming was not

118 detected until 1999 in the Western Caribbean (Figures 3; Supplementary Figure 4;

119 Supplementary Table 2). So, although the Western Caribbean began warming much later, 120 recently it has warmed at a substantially higher rate of $0.24{ }^{\circ} \mathrm{C}$ per decade. Since recent 121 rapid warming began in each region, warming rates ranged from about $0.17^{\circ} \mathrm{C}$ per decade 122 on Bahamian reefs to $0.26{ }^{\circ} \mathrm{C}$ per decade on reefs in the Southern and Eastern Caribbean 123 (Figure 3; Supplementary Table 2). Overall, these warming rates translate to an increase 124 in annual coral reef temperatures between 0.53 and $0.99{ }^{\circ} \mathrm{C}$ over the last 30 years. Subregional patterns of warming across the Caribbean calculated here are similar to

126 other SST parameters used for assessing thermal risk on coral reefs, such as degree

127 heating weeks (accumulation of temperature anomalies exceeding the monthly maximum

128 mean SST ${ }^{16}$; DHW). Ecoregions within the Caribbean with faster rates of warming (e.g.,

129 Southern and Eastern Caribbean [mean $0.26{ }^{\circ} \mathrm{C}$ per decade], Supplementary Table 2)

130 have also been reported to have some of the highest occurrences of weekly SST anomalies

$131{ }^{28}$, maximum DHWs ${ }^{16}$, and coral bleaching or mortality risk events ${ }^{29}$. The variability in

132 warming parameters across Caribbean ecoregions is likely a significant contributor to

133 differences in coral cover among these regions since the mid $1990 \mathrm{~s}^{30}$. 


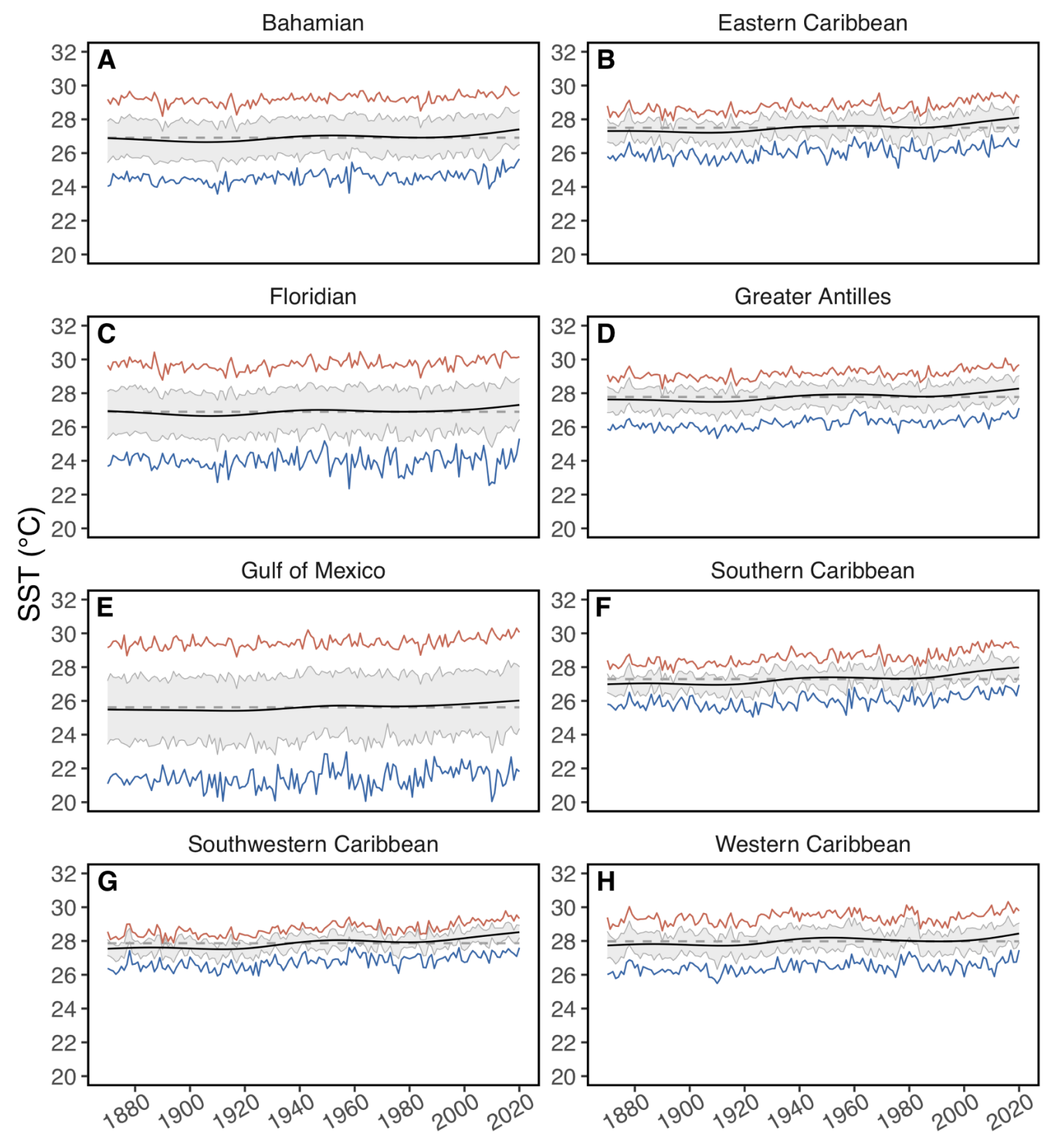

135 Figure 3. Historic SST trends on coral reefs within ecoregions (1871-2020). Long-term

136 SST records (HadISST) on Caribbean coral reefs separated by ecoregion depicting GAM

137 smoothed annual mean SST time (black line), annual maximum (red line), and annual

138 minimum (blue line) SST. The grey dashed horizontal line denotes the mean SST over the

139 entire period and the grey ribbon represents the $95 \%$ confidence interval around the true

140 annual SST mean for each ecoregion. 
While increasing SST on Caribbean coral reefs is clearly a major concern, warming is not limited to reef locations. Sea surface temperatures are rising across the entire Caribbean

143 basin at a mean rate of $0.04^{\circ} \mathrm{C}$ per decade since 1871 (HadISST data; Supplementary

144 Figure 6) and more rapidly since 1981 at $0.23^{\circ} \mathrm{C}$ per decade (Pathfinder SST data; Figure

145 4A; Supplementary Figure 6). This recent rate of ocean warming $\left(0.23^{\circ} \mathrm{C}\right.$ per decade from

$1461981-2019)$ is similar to those previously calculated for the Caribbean basin. For example,

147 Chollett et al. ${ }^{19}$ reported a rate for the entire Caribbean and southeastern Gulf of Mexico of

$148 \quad 0.27^{\circ} \mathrm{C}$ per decade (1985-2009). It is clear that the Caribbean basin is experiencing rapid

149 warming (Figure 2B, 3, 4A; Supplementary Figures 6, and 7). Additionally, rapid increases

150 in ocean heat content across the region has been apparent ${ }^{31}$, driving increases in other

151 severe events such as increased storm activity and marine heatwaves (MHWs).

A
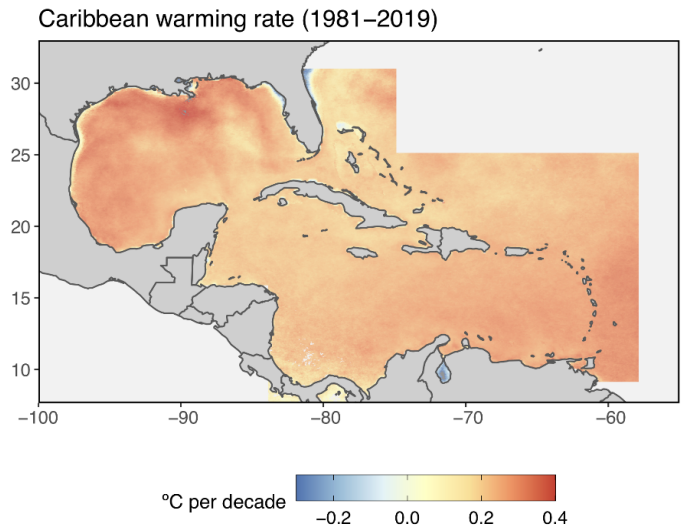

B
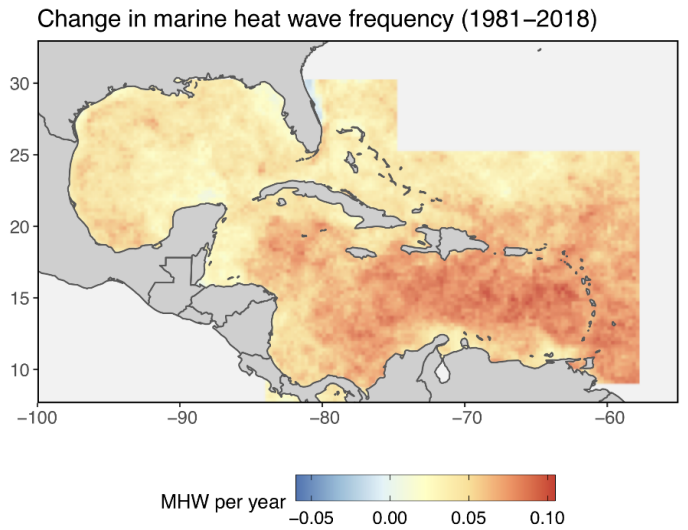

155 Figure 4. Warming patterns throughout the Caribbean Sea. Increasing warming events across the Caribbean depicted through $\mathbf{A})$ rate of SST change $\left({ }^{\circ} \mathrm{C}\right.$ per decade) from 1981 to 2019 (Pathfinder; mean slope $0.23 \pm 0.07^{\circ} \mathrm{C}$ per decade) and $\mathrm{B}$ ) increasing marine heatwave events (slope of counts per year). Grey ocean area was not included in these analyses. 

changes in marine heatwaves on Caribbean coral reefs. Marine heatwaves (MHW) are

163 discrete warming events characterized by rate of onset, duration of event (five days or

164 longer), and the intensity of warming ${ }^{32}$. Over the past several decades, MHW have

165 increased in both frequency and duration globally ${ }^{33}$. Likewise, we found that heatwaves are

Figure 5) and on Caribbean coral reefs (Figure 5A; Supplementary Tables 3 and 4). The average frequency of MHW events on Caribbean coral reefs has increased from about 1 per year in the 1980s to almost 5 per year in the 2010s (Figure 5A; Supplementary Table 4), with current events lasting on average about 14 days each (Figure 5B; Supplementary

Table 4). Additionally, the decadal mean return time (number of days elapsed since the last
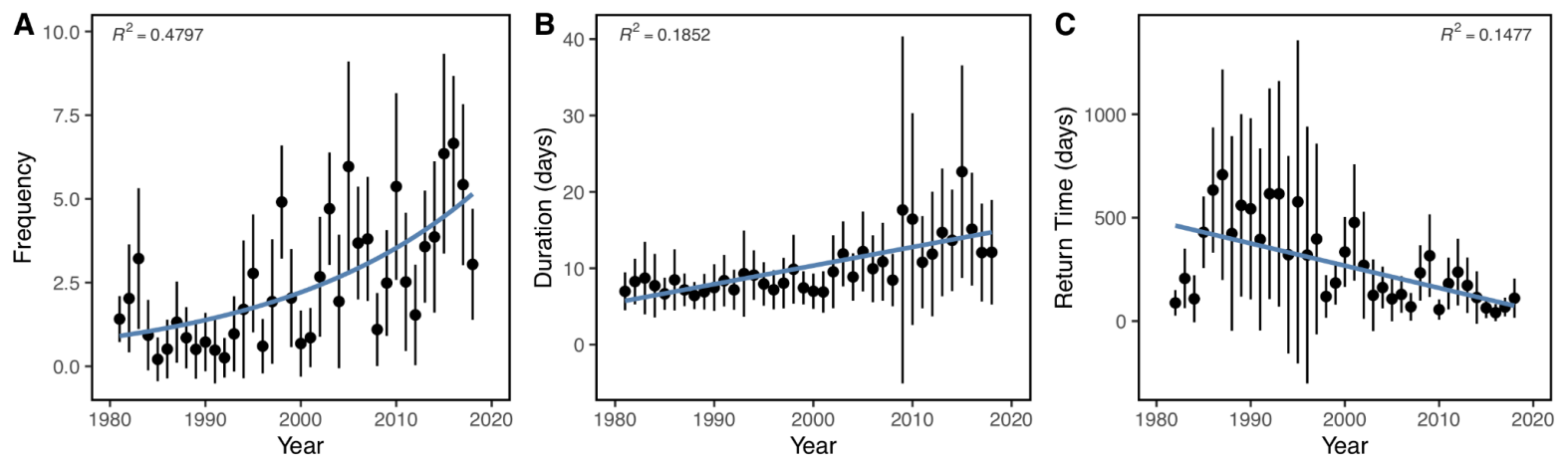

177 Figure 5. MHW trends (1981-2018) across Caribbean coral reefs. Temperature data are

178 based on OISST gridded data to determine $\mathrm{A}$ ) marine heat wave (MHW) frequency (number events per year) with Nagelkerke pseudo R²; B) MHW duration (number days per event) with linear model $\mathrm{R}^{2}$; and $\mathrm{C}$ ) return time (number days per event) since the previous MHW event with linear model $R^{2}$ reported. Points denote annual mean values $( \pm S D)$ and blue lines represent linear (Im or glm) trends. 
Figure 8), however, coral reefs within the Eastern Caribbean are experiencing the greatest increase in MHW duration compared to the 1980s (Supplementary Figure 8;

Supplementary Table 4), while the change in frequency of MHWs was the lowest on

variations in $\mathrm{MHW}$ events across ecoregions further highlights differences in subregional scales. primary cause of mass-coral mortality across the Caribbean. In fact, a recent study demonstrated a positive correlation between MHW duration and the frequency of coral bleaching across the Caribbean and Gulf of Mexico ${ }^{34}$. However, these severe heating events are often missed with current coral bleaching monitoring in place, such as DHWs, because of the cumulative nature of these alert systems ${ }^{35,36}$. Even with longer MHW events being detected through these traditional coral bleaching monitoring systems, the ecological impact MHWs have on coral reef ecosystems are distinct. MHWs are known to trigger rapid bleaching and mass coral mortality on reefs that impact species with all levels of thermal tolerance and on highly localized spatial scales ${ }^{36,37}$.

\section{Conclusions}

The remarkable collapse of Caribbean coral reef ecosystems began when ocean heating in the region accelerated $\sim 30$ years ago. Not only has warming been the primary driver of widespread coral mortality, but it has indirectly (via habitat loss) likely affected countless non-coral reef inhabitants when their own thermal tolerances were exceeded ${ }^{38-41}$. And yet, this ecosystem transformation was caused by a mere $1{ }^{\circ} \mathrm{C}$ of warming (or substantially less in some ecoregions). This fact strongly suggests that we will lose what little 
remains in the coming years and decades if the anthropogenic heating of the Caribbean sea

211 continues at this rate ${ }^{42}$. Another 0.6 or $1.6^{\circ} \mathrm{C}$ of warming (which based on our current

212 warming rates would occur mid- and end-of-century, respectively) is likely a best case

213 scenario at this point since oceans will continue to absorb excess heat even if global carbon

214 neutrality goals are met. Despite the uncertainties of future ocean warming patterns, it is

215 clear that the last 150 years of warming on Caribbean coral reefs have drastically altered

216 these ecosystems and it will take significant global efforts to prevent the total loss of these

217 remaining coral reefs.

219 Methods

220

Reef Locations

221

We compiled a Caribbean coral reef location database by sourcing latitude and longitude

coordinates for known coral reef locations from the following sources: UNEP World

Conservation Monitoring Center ${ }^{43}$, the Global Coral Reef Monitoring Program ${ }^{44}$, the Atlantic and Gulf Rapid Reef Assessment (AGRRA) ${ }^{45}$, Reef Check (reefcheck.org), Florida's Coral Reef Evaluation and Monitoring Program (CREMP) ${ }^{46}$, the US Virgin Islands Territorial Coral Reef Monitoring Program (TCRMP) ${ }^{47}$, and previously published survey data for the region ${ }^{30}$. Sites were considered duplicates if they had the same GPS coordinates. In total, we identified 5,326 unique reefs across the Caribbean basin that were assigned to ecoregions based on the World Wildlife Fund (WWF) marine ecoregion classifications ${ }^{27}$. Ecoregions contained between 84 (Gulf of Mexico) and 1,277 (Greater Antilles) reef locations (Figure 1). This database was used to assess SST and MWH trends across Caribbean coral reefs.

\section{Sea Surface Temperature Datasets}

234 Our characterization of the thermal history of the Caribbean was based on three complementary ocean temperature datasets: HadISST from the United Kingdom Met Office 
237 Optimum Interpolation Sea Surface Temperature (OISST) ${ }^{52}$. We combined the HadISST

238 and Pathfinder databases to assess both long-term and high-resolution SST trends across

239 the Caribbean and solely on coral reefs. Additionally, we used the OISST database to

240 identify and assess marine heatwave (MHW) events.

241 We obtained monthly SST from 1871 to 2020 from the HadISST dataset ${ }^{53,54}$ at a

242 resolution of $1^{\circ}$ grids across the Caribbean $\left(0^{\circ} \mathrm{N}-40^{\circ} \mathrm{N} ; 100^{\circ} \mathrm{W}-55^{\circ} \mathrm{W}\right)$. The HadISST data

243 are based on a combination of temperature reconstruction and observational data to

244 produce a long-term record of in situ measurements (typically from ships and buoys) and

245 satellite-derived temperatures. HadISST uses in situ SST data from the Met Office Marine

246 Data Bank (MDB) and is supplemented with data from the Comprehensive Ocean-

247 Atmospheric Data Set (ICOADS) when missing from the MDB between the years 1871 and

248 1995. Satellite SST data from the Global Telecommunications System are included in the

249 HadISST dataset after 1982, making this database ideal for long-term SST assessments $250 \quad 54,55$.

Additionally, we calculated monthly mean SST at $4 \mathrm{~km}$ resolution from September 1981 to December 2019 using the twice daily (night and day) Pathfinder Version 5.3 database ${ }^{49,50}$. Pathfinder SST data were clipped to the wider Caribbean constraints and quality filtered (quality four or greater ${ }^{50,51}$ ) before the mean monthly SST value was calculated per grid cell and concatenated into a single netCDF file. The Pathfinder database is derived from measurements made by the Advanced Very High Resolution Radiometer (AVHRR) instruments aboard NOAA's polar orbiting satellites that combine multiple passes of data. These data were provided by GHRSST and the NOAA National Centers for Environmental Information. temperature climatology and detect MHW events across the Caribbean basin from 1982 to $2018^{52,56}$. OISST data are constructed by combining both in situ (collected via ships and buoys) and infrared satellite (AVHRR instruments) SST, applying a bias adjustment to satellite and ship observation data, and filling gaps as necessary through interpolation. The 
265

266

267

268

269

270

271

272

273

274

275

276

277

278

279

280

281

282

283

284

285

286

287

288

289

290

291

combination of high resolution and multiple sources of SST observations is ideal for identifying MHWs, and is frequently used for such assessments ${ }^{32,57}$.

\section{Historic SST Assessment}

We examined the rate of SST change through time for the wider Caribbean region using the HadISST (1871-2020) and Pathfinder (1981-2019) databases (described above) to evaluate historic SST trends. A simple linear model was applied to each grid cell through time (months each year) of both datasets to calculate the slope and significance of SST increases over time for the full region. Additionally, we extracted SST from the HadISST and Pathfinder datasets using a compiled Caribbean coral reef location database (raster package; version $2.9-23^{58}$ ). The use of satellite-derived SST measurements to represent benthic temperature patterns has been frequently assessed via comparisons of different databases with in situ logger measurements at the same locations. While these studies report that satellite-derived measurements often underestimate in situ temperatures ${ }^{59,60}$, the consensus is that satellite databases accurately reflect temperature conditions on many coral reefs at depth ${ }^{60-62}$ and are a useful tool for identifying global warming signals ${ }^{53}$. Monthly SST measurements were averaged across all reef locations to assess historic SST trends on Caribbean coral reefs per sampling period (month) as well as within individual ecoregions. We assessed annual SST on coral reefs since 1871 using a generalized additive model (GAM) with a cubic regression spline for year and a cyclic cubic regression spline for month to smooth temperature variability through time for better assessment of temporal SST trends on reefs. We then identified the year in which annual warming rates significantly increased based on the first derivative of the GAM curve for the entire region as well as each ecoregion ${ }^{63}$. These years were used to calculate the mean warming rate since the identified inflection points for coral reefs within the eight ecoregions. All analyses and visualizations were conducted using $R$ version $3.6 .1^{64}$. 
293 Marine heatwaves (MHW) are defined as anomalously warm sea-surface temperature

294 events, with temperatures warmer than historical climatology for that specific time and 295 location, lasting for at least a 5 day period ${ }^{32}$. We used NOAA's OISST data (described above) to identify and assess MHWs across the wider Caribbean from $1982-2018{ }^{65}$. If successive events had less than two days between them, they were considered to be the same event. We used the heatwaveR package in $\mathrm{R}$ (version 0.4 .4$)^{66}$ and code provided from the marine heatwave working group (www.marineheatwaves.org) to identify marine heatwave events from our OISST dataset and calculate heatwave metrics (Supplementary

For each pixel, we aggregated a list of distinct MHW events between 1982 and 2018, between each unique MHW event. All other metrics were averaged annually.

To evaluate MHW trends across the Caribbean basin, we created an annual time series for each MHW pixel that contains the number of distinct MHW events, total number of MHW days experienced, the average maximum (peak) intensity $\left({ }^{\circ} \mathrm{C}\right)$ for all events that year, the average duration (days) of all events that year, the average onset rate for all events that year

$314\left({ }^{\circ} \mathrm{C}\right.$ per day), and the average time elapsed since a previous event (days). We then

315 calculated a history of MHW events for each coral reef location using a nearest neighbor analysis to match reef locations to MHW events identified from the OISST grids. 
bioRxiv preprint doi: https://doi.org/10.1101/2021.05.12.443696; this version posted May $13,2021$. The copyright holder for this preprint

(which was not certified by peer review) is the author/funder, who has granted bioRxiv a license to display the preprint in perpetuity. It is made available under aCC-BY-NC-ND 4.0 International license.

319 variables are count data and best analyzed using generalized linear models (GLM) (Ime4;

320 version 1.1-23) ${ }^{67}$. The response variables for OLS models were log transformed to meet

321 model assumptions when necessary. For MHW trends on coral reefs, the level of

322 observation was each unique MHW pixel that overlapped coral reef habitat and we modeled

323 trends for each ecoregion to account for potential spatial differences in MHW metrics across

324 the Caribbean basin. Significance and $R^{2}$ values are obtained to evaluate the strength of

325 each trend. For GLM trends, we report the Nagelkerke pseudo $\mathrm{R}^{2}$ value. 
326 Acknowledgements: This paper was funded in part by a grant from the National Science

327 Foundation to JFB (OCE 1737071). We thank the following data providers: Atlantic Gulf

328 Rapid Reef Assessment (AGRRA) contributors and data managers; the Reef Check

329 Foundation, UNEP World Conservation Monitoring Center, the Global Coral Reef Monitoring

330 Program, Florida's Coral Reef Evaluation and Monitoring Program (CREMP), and the US

331 Virgin Islands Territorial Coral Reef Monitoring Program (TCRMP). We thank Matthew

332 Kendall for his assistance with cluster development and support with acquiring satellite data

333 and S. Williams, H. Reich, J. Rippe, and J. Baumann for their helpful feedback on early

334 drafts of the manuscript.

336 Data Accessibility: HadISST data can be accessed at

337 www.metoffice.gov.uk/hadobs/hadisst/, Pathfinder data can be accessed at

338 www.ncei.noaa.gov/data/oceans/pathfinder/Version5.3/L3C/, and OISST data can be

339 accessed at www.ncdc.noaa.gov/oisst/data-access. All data and code compiled for this

340 manuscript can be freely accessed on GitHub (github.com/seabove7/CaribbeanSST) and

341 Zendo (DOI: 10.5281/zenodo.4751658), including links to the compiled databases used here

342 from the three sources listed above.

344 Author Contributions: All authors conceived the idea and contributed intellectually to its

345 development. CBB led the SST analyses and LM led the MHW analyses. CBB and JFB led

346 the manuscript preparation with contributions from LM.

348 Competing Interests statement: The authors declare no conflicts of interest. 


\section{Literature Cited}

350

1. Cheng, L. et al. Improved estimates of ocean heat content from 1960 to 2015. Sci. Adv. 3, e1601545 (2017).

2. Levitus, S. et al. World ocean heat content and thermosteric sea level change (0-2000 m), 1955-2010: WORLD OCEAN HEAT CONTENT. Geophys. Res. Lett. 39, n/a-n/a (2012).

3. Poloczanska, E. S. et al. Global imprint of climate change on marine life. Nature Climate Change 3, 919-925 (2013).

4. Seibel, B. A. \& Drazen, J. C. The rate of metabolism in marine animals: environmental constraints, ecological demands and energetic opportunities. Philosophical Transactions of the Royal Society B: Biological Sciences 362, 2061-2078 (2007).

5. Newell, R. C. \& Branch, G. M. The Influence of Temperature on the Maintenance of Metabolic Energy Balance in Marine Invertebrates. in Advances in Marine Biology (eds. Blaxter, J. H. S., Russell, F. S. \& Yonge, M.) vol. 17 329-396 (Academic Press, 1980).

6. Bruno, J. F., Carr, L. A. \& O'Connor, M. I. Exploring the role of temperature in the ocean through metabolic scaling. Ecology 96, 3126-3140 (2015).

7. Harvell, C. D. et al. Climate warming and disease risks for terrestrial and marine biota. Science 296, 2158-2162 (2002).

8. Pershing, A. et al. Oceans and marineresources: Impacts, risks, and adaptation in the United States. The fourth National Climate Assessment, Volume II, chapter 9. https://nca2018.globalchange.gov/chapter/9/ (2018) doi:10.7930/NCA4.2018.CH9.

9. Robinson, J. P. W., Wilson, S. K., Jennings, S. \& Graham, N. A. J. Thermal stress induces persistently altered coral reef fish assemblages. Global Change Biology 25, 2739-2750 (2019).

10. Hughes, T. P. et al. Global warming transforms coral reef assemblages. Nature 556, 492-496 (2018).

11. Graham, N. A. J., Jennings, S., MacNeil, M. A., Mouillot, D. \& Wilson, S. K. Predicting 
climate-driven regime shifts versus rebound potential in coral reefs. Nature 518, 94-97 (2015).

12. Gardner, T. A., Côté, I. M., Gill, J. A., Grant, A. \& Watkinson, A. R. Long-Term RegionWide Declines in Caribbean Corals. Science 301, 958-960 (2003).

13. Alvarez-Filip, L., Dulvy, N. K., Gill, J. A., Côté, I. M. \& Watkinson, A. R. Flattening of Caribbean coral reefs: region-wide declines in architectural complexity. Proceedings of the Royal Society B: Biological Sciences 276, 3019-3025 (2009).

14. Hoegh-Guldberg, O. Climate change, coral bleaching and the future of the world's coral reefs. Mar. Freshwater Res. (1999) doi:10.1071/MF99078.

15. Woesik, R. van \& Randall, C. J. Coral disease hotspots in the Caribbean. Ecosphere 8, e01814 (2017)

16. Eakin, C. M. et al. Caribbean Corals in Crisis: Record Thermal Stress, Bleaching, and Mortality in 2005. PLoS One 5, (2010).

17. Bahr, K. D., Rodgers, K. S. \& Jokiel, P. L. Ocean warming drives decline in coral metabolism while acidification highlights species-specific responses. Marine Biology Research 14, 924-935 (2018).

18. Harianto, J., Nguyen, H. D., Holmes, S. P. \& Byrne, M. The effect of warming on mortality, metabolic rate, heat-shock protein response and gonad growth in thermally acclimated sea urchins (Heliocidaris erythrogramma). Mar Biol 165, 96 (2018).

19. Chollett, I., Müller-Karger, F. E., Heron, S. F., Skirving, W. \& Mumby, P. J. Seasonal and spatial heterogeneity of recent sea surface temperature trends in the Caribbean Sea and southeast Gulf of Mexico. Marine Pollution Bulletin 64, 956-965 (2012).

20. Cheng, L., Abraham, J., Hausfather, Z. \& Trenberth, K. E. How fast are the oceans warming? Science 363, 128-129 (2019). surface temperatures and coral reef bleaching off La Parguera, Puerto Rico (northeastern Caribbean Sea). Coral Reefs 17, 377-382 (1998).

403 22. Gill, J. A., Watkinson, A. R., McWilliams, J. P. \& Cote, I. M. Opposing forces of aerosol 
404

405

406

407

408

409

410

411

412

413

414

415

416

417

418

419

420

421

422

423

424

425

426

427

428

429

430

431

cooling and EI Nino drive coral bleaching on Caribbean reefs. Proceedings of the National Academy of Sciences 103, 18870-18873 (2006).

23. Barton, A. D. \& Casey, K. S. Climatological context for large-scale coral bleaching. Coral Reefs 24, 536-554 (2005).

24. Hoegh-Guldberg, O. Climate change, coral bleaching and the future of the world's coral reefs. Marine and Freshwater Research 50, 839-866 (1999).

25. Kuffner, I. B., Lidz, B. H., Hudson, J. H. \& Anderson, J. S. A Century of Ocean Warming on Florida Keys Coral Reefs: Historic In Situ Observations. Estuaries and Coasts 38, 1085-1096 (2015).

26. Bruno, J. F. et al. Climate change threatens the world's marine protected areas. Nature Clim Change 8, 499-503 (2018).

27. Spalding, M. D. Marine Ecoregions of the World: a bioregionalization of coast and shelf areas: Working notes, 2010. (2010).

28. Selig, E. R., Casey, K. S. \& Bruno, J. F. New insights into global patterns of ocean temperature anomalies: implications for coral reef health and management. Global Ecology and Biogeography 19, 397-411 (2010).

29. Muñiz-Castillo, A. I. et al. Three decades of heat stress exposure in Caribbean coral reefs: a new regional delineation to enhance conservation. Sci Rep 9, (2019).

30. Schutte, V., Selig, E. \& Bruno, J. Regional spatio-temporal trends in Caribbean coral reef benthic communities. Mar. Ecol. Prog. Ser. 402, 115-122 (2010).

31. Cheng, L. et al. Upper Ocean Temperatures Hit Record High in 2020. Adv. Atmos. Sci. (2021) doi:10.1007/s00376-021-0447-x.

32. Hobday, A. J. et al. A hierarchical approach to defining marine heatwaves. Progress in Oceanography 141, 227-238 (2016).

33. Oliver, E. C. J. et al. Longer and more frequent marine heatwaves over the past century. Nature Communications 9, 1324 (2018).

34. Smale, D. A. et al. Marine heatwaves threaten global biodiversity and the provision of ecosystem services. Nature Climate Change 9, 306-312 (2019). 
35. Liu, G. et al. NOAA Coral Reef Watch's 5km Satellite Coral Bleaching Heat Stress Monitoring Product Suite Version 3 and Four-Month Outlook Version 4. 32, 7 (2017).

36. Fordyce, A. J., Ainsworth, T. D., Heron, S. F. \& Leggat, W. Marine Heatwave Hotspots in Coral Reef Environments: Physical Drivers, Ecophysiological Outcomes, and Impact Upon Structural Complexity. Front. Mar. Sci. 6, (2019).

37. Le Nohaïc, M. et al. Marine heatwave causes unprecedented regional mass bleaching of thermally resistant corals in northwestern Australia. Scientific Reports 7, 14999 (2017).

38. Habary, A., Johansen, J. L., Nay, T. J., Steffensen, J. F. \& Rummer, J. L. Adapt, move or die - how will tropical coral reef fishes cope with ocean warming? Global Change Biology 23, 566-577 (2017).

39. Stuart-Smith, R. D., Brown, C. J., Ceccarelli, D. M. \& Edgar, G. J. Ecosystem restructuring along the Great Barrier Reef following mass coral bleaching. Nature 560, 92-96 (2018).

40. Jones, G. P., McCormick, M. I., Srinivasan, M. \& Eagle, J. V. Coral decline threatens fish biodiversity in marine reserves. Proc Natl Acad Sci USA 101, 8251-8253 (2004).

41. Pratchett, M. S. et al. Effects of climate-induced coral bleaching on coral-reef fishes ecological and economic consequences. in Oceanography and marine biology: an annual review vol. 46 251-296 (CRC Press, 2008).

42. Frieler, K. et al. Limiting global warming to $2^{\circ} \mathrm{C}$ is unlikely to save most coral reefs. Nature Climate Change 3, 165-170 (2013).

43. UNEP-WCMC, WorldFish Centre, WRI \& TNC. Global distribution of warm-water coral reefs, compiled from multiple sources including the Millennium Coral Reef Mapping Project. UN Environment World Conservation Monitoring Centre Version 4.0, (2018).

44. Jackson, E. J., Donovan, M., Cramer, K. \& Lam, V. Status and trends of Caribbean coral reefs: 1970-2012. 306 (2012).

45. Marks, K. W. AGRRA Database, version (2018-03). (2018).

46. Porter, J. \& Stossel, M. Coral Reef Evaluation and Monitoring Project Florida Keys 2001. (2020). 
460

461

462

463

464

465

466

467

468

469

470

471

472

473

474

475

476

477

478

479

480

481

482

483

484

485

486

487

47. Smith, T. et al. The United States Virgin Islands Territorial Coral Reef Monitoring Program. 2016 Annual Report. (2016).

48. Rayner, N. A. Global analyses of sea surface temperature, sea ice, and night marine air temperature since the late nineteenth century. J. Geophys. Res. 108, 4407 (2003).

49. Korak, S. et al. AVHRR Pathfinder version 5.3 level 3 collated (L3C) global $4 \mathrm{~km}$ sea surface temperature for 1981-Present. (2018) doi:10.7289/V52J68XX.

50. Casey, K. S., Brandon, T. B., Cornillon, P. \& Evans, R. The Past, Present, and Future of the AVHRR Pathfinder SST Program. in Oceanography from Space (eds. Barale, V., Gower, J. F. R. \& Alberotanza, L.) 273-287 (Springer Netherlands, 2010). doi:10.1007/978-90-481-8681-5_16.

51. Kilpatrick, K. A., Podestá, G. P. \& Evans, R. Overview of the NOAA/NASA advanced very high resolution radiometer Pathfinder algorithm for sea surface temperature and associated matchup database. Journal of Geophysical Research: Oceans 106, 9179_ 9197 (2001).

52. Reynolds, R. W. et al. Daily High-Resolution-Blended Analyses for Sea Surface Temperature. Journal of Climate 20, 5473-5496 (2007).

53. Kent, E. C. \& Kennedy, J. J. Historical Estimates of Surface Marine Temperatures. Annual Review of Marine Science 13, 283-311 (2021).

54. Sheppard, C. \& Rayner, N. A. Utility of the Hadley Centre sea ice and sea surface temperature data set (HadISST1) in two widely contrasting coral reef areas. Marine Pollution Bulletin 44, 303-308 (2002).

55. Lough, J. M., Anderson, K. D. \& Hughes, T. P. Increasing thermal stress for tropical coral reefs: 1871-2017. Scientific Reports 8, 6079 (2018).

56. Reynolds, R. W., Rayner, N. A., Smith, T. M., Stokes, D. C. \& Wang, W. An Improved In Situ and Satellite SST Analysis for Climate. Journal of Climate 15, 1609-1625 (2002).

57. Couch, C. S. et al. Mass coral bleaching due to unprecedented marine heatwave in Papahānaumokuākea Marine National Monument (Northwestern Hawaiian Islands). PLOS ONE 12, e0185121 (2017). 
488

489

490

491

492

493

58. Hijmans, R. J. raster: Geographic Data Analysis and Modeling. (2019).

59. Castillo, K. D. \& Lima, F. P. Comparison of in situ and satellite-derived (MODISAqua/Terra) methods for assessing temperatures on coral reefs. Limnology and Oceanography: Methods 8, 107-117 (2010).

60. Gomez, A. M. et al. Comparison of Satellite-Based Sea Surface Temperature to In Situ Observations Surrounding Coral Reefs in La Parguera, Puerto Rico. Journal of Marine Science and Engineering 8, 453 (2020).

61. Claar, D. C., Cobb, K. M. \& Baum, J. K. In situ and remotely sensed temperature comparisons on a Central Pacific atoll. Coral Reefs 38, 1343-1349 (2019).

62. Bruno, J. F., Siddon, C. E., Witman, J. D., Colin, P. L. \& Toscano, M. A. El Niño related coral bleaching in Palau, Western Caroline Islands. Coral Reefs 20, 127-136 (2001).

63. Bennion, H., Simpson, G. L. \& Goldsmith, B. J. Assessing degradation and recovery pathways in lakes impacted by eutrophication using the sediment record. Front. Ecol. Evol. 3, (2015).

64. R Core Team. R: A Language and Environment for Statistical Computing. (R Foundation for Statistical Computing, 2018).

65. Banzon, V., Smith, T. M., Steele, M., Huang, B. \& Zhang, H.-M. Improved Estimation of Proxy Sea Surface Temperature in the Arctic. J. Atmos. Oceanic Technol. 37, 341-349 (2020).

66. Schlegel, R. W. \& Smit, A. J. heatwaveR: A central algorithm for the detection of heatwaves and cold-spells. Journal of Open Source Software 3, 821 (2018).

67. Bates, D. \& Maechler, M. Fitting Linear Mixed-Effects Models Using \{lme4\}. Journal of Statistical Software 67, 1-48 (2015).

68. Casey, K. S. \& Cornillon, P. Global and regional sea surface temperature trends. Journal of Climate 14, 3801-3818 (2001).

69. Lawrence, S. P., Llewellyn-Jones, D. T. \& Smith, S. J. The measurement of climate change using data from the Advanced Very High Resolution and Along Track Scanning Radiometers. J. Geophys. Res. 109, n/a-n/a (2004). 
516 70. Good, S. A., Corlett, G. K., Remedios, J. J., Noyes, E. J. \& Llewellyn-Jones, D. T. The

517 global trend in sea surface temperature from 20 years of Advanced Very High

518 Resolution Radiometer Data. Journal of Climate 20, 1255-1264 (2007).

519 71. Burrows, M. T. et al. The Pace of Shifting Climate in Marine and Terrestrial Ecosystems.

$520 \quad$ Science 334, 652-655 (2011).

521 72. USGCRP. Climate Science Special Report. 1-470

522

https://science2017.globalchange.gov/chapter/executive-summary/.

523

524

525

526

527

528

529

530 


\section{$531 \quad$ Figure Captions}

532 Figure 1. Caribbean coral reef site locations and ecoregion designation. The colour of

533 each reef represents the designated ecoregion and $n$ denotes the number of unique reef

534 locations within that ecoregion.

535

536 Figure 2. Historic SST trend on Caribbean coral reefs (1871-2020). Long-term SST

537 records (HadISST) on Caribbean coral reefs depicting A) mean monthly SST each year

538 (represented by line colour: blue to red) and B) GAM smoothed annual mean SST time

539 (black line), annual maximum (red line), and annual minimum (blue line) SST. The grey

540 dashed horizontal line denotes the overall mean SST for all sites over the entire period (27.3

$541{ }^{\circ} \mathrm{C}$ ) and the grey ribbon represents the 95\% confidence interval around the annual mean

542 SST through time.

543

544 Figure 3. Historic SST trends on coral reefs within ecoregions (1871-2020). Long-term

545 SST records (HadISST) on Caribbean coral reefs separated by ecoregion depicting GAM

546 smoothed annual mean SST time (black line), annual maximum (red line), and annual

547 minimum (blue line) SST. The grey dashed horizontal line denotes the mean SST over the

548 entire period and the grey ribbon represents the $95 \%$ confidence interval around the true

549 annual SST mean for each ecoregion.

550

551 Figure 4. Warming patterns throughout the Caribbean Sea. Increasing warming events across the Caribbean depicted through $\mathbf{A})$ rate of SST change $\left({ }^{\circ} \mathrm{C}\right.$ per decade) from 1981 to

5532019 (Pathfinder; mean slope $0.23 \pm 0.07^{\circ} \mathrm{C}$ per decade) and $\mathrm{B}$ ) increasing marine

555 Figure 5. MHW trends (1981-2018) across Caribbean coral reefs. Temperature data are

556 based on OISST gridded data to determine A) marine heat wave (MHW) frequency (number 
bioRxiv preprint doi: https://doi.org/10.1101/2021.05.12.443696; this version posted May 13, 2021. The copyright holder for this preprint

(which was not certified by peer review) is the author/funder, who has granted bioRxiv a license to display the preprint in perpetuity. It is made available under aCC-BY-NC-ND 4.0 International license.

557 events per year) with Nagelkerke pseudo R $^{2}$; B) MHW duration (number days per event) with

558 linear model $\mathrm{R}^{2}$; and $\mathrm{C}$ ) return time (number days per event) since the previous MHW event

559 with linear model $R^{2}$ reported. Points denote annual mean values $( \pm S D)$ and blue lines

560 represent linear (Im or glm) trends.

561

562

563

564

565

566 


\section{Tables}

568 Table 1. Estimated warming rates from both HadISST and Pathfinder databases for different

569 temporal ranges. Values are means of all 5,326 reef locations included in the study. The

570 year 1987 was estimated as the beginning of the most recent period of warming across all

571 Caribbean coral reefs (see Supplementary Figure 1).

572

\begin{tabular}{|c|c|c|c|c|c|}
\hline $\begin{array}{c}\text { Temperature } \\
\text { parameter }\end{array}$ & $\begin{array}{c}\text { HadISST } \\
(\mathbf{1 8 7 1 - 2 0 2 0})\end{array}$ & $\begin{array}{c}\text { HadISST } \\
(\mathbf{1 9 8 1 - 2 0 2 0})\end{array}$ & $\begin{array}{c}\text { HadISST } \\
\mathbf{( 1 9 8 7 - 2 0 2 0 )}\end{array}$ & $\begin{array}{c}\text { Pathfinder } \\
\mathbf{( 1 9 8 1 - 2 0 1 9 )}\end{array}$ & $\begin{array}{c}\text { Pathfinder } \\
\mathbf{( 1 9 8 7 - 2 0 1 9 )}\end{array}$ \\
\hline $\begin{array}{c}\text { Caribbean Basin } \\
\left({ }^{\circ} \mathrm{C} \text { per decade) }\right.\end{array}$ & 0.04 & 0.17 & 0.18 & 0.23 & NA \\
\hline $\begin{array}{c}\text { Caribbean Basin } \\
\left(\text { total }{ }^{\circ} \mathrm{C} \text { for period) }\right.\end{array}$ & 0.60 & 0.68 & 0.61 & 0.90 & NA \\
\hline $\begin{array}{c}\text { Caribbean Reefs } \\
\left({ }^{\circ} \mathrm{C} \text { per decade) }\right.\end{array}$ & 0.04 & 0.15 & 0.16 & 0.19 & 0.20 \\
\hline $\begin{array}{c}\text { Caribbean Reefs } \\
\text { (total }{ }^{\circ} \mathrm{C} \text { for period) }\end{array}$ & 0.60 & 0.60 & 0.54 & 0.74 & 0.66 \\
\hline
\end{tabular}

573

574 Table 2. Published reports of global ocean surface warming rates.

\begin{tabular}{|l|l|l|}
\hline Study & ${ }^{\circ} \mathrm{C}$ per decade & Years \\
\hline Casey and Cornillon $2001^{68}$ & 0.14 & $1960-1990$ \\
\hline Lawrence et al. 2004 & & \\
\hline Good et al. 2007 & & \\
\hline Burrows et al. $2011^{71}$ & 0.09 and 0.13 & $1985-2000$ \\
\hline USGCRP 2017 & 0.17 & $1985-2004$ \\
\hline
\end{tabular}




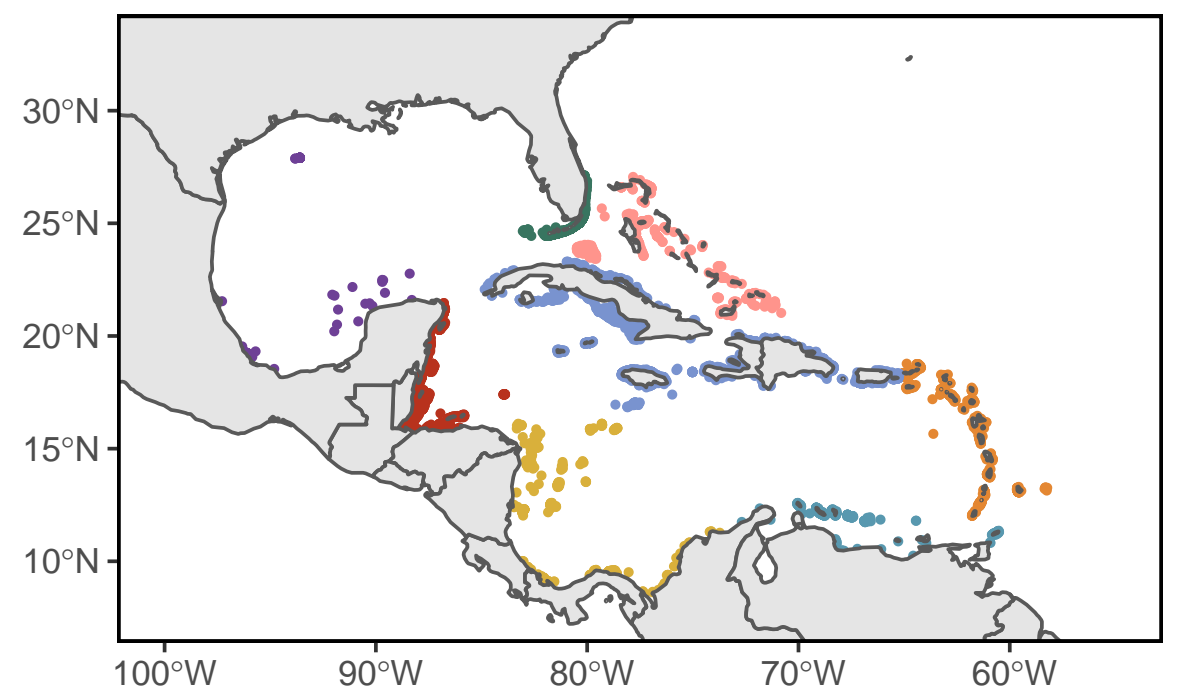

\section{Ecoregion}

- Bahamian $(n=407)$

- Eastern Caribbean ( $n=914)$

- Floridian $(n=880)$

- Greater Antilles $(n=1277)$

- Gulf of Mexico ( $n=84)$

- Southern Caribbean ( $n=367)$

- Southwestern Caribbean $(n=365)$

- Western Caribbean $(n=1032)$ 
Bahamian

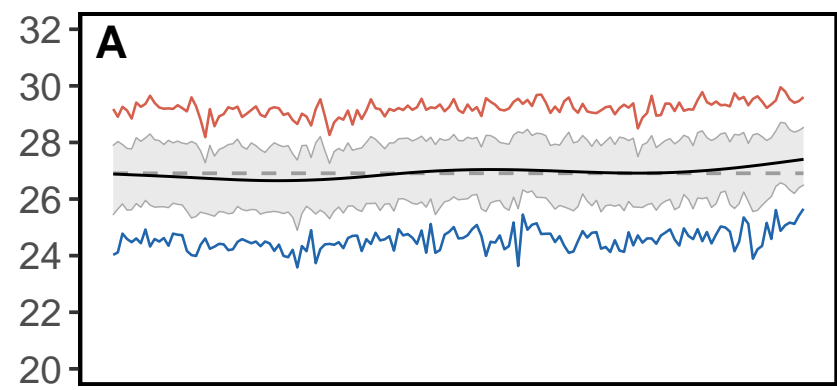

Floridian

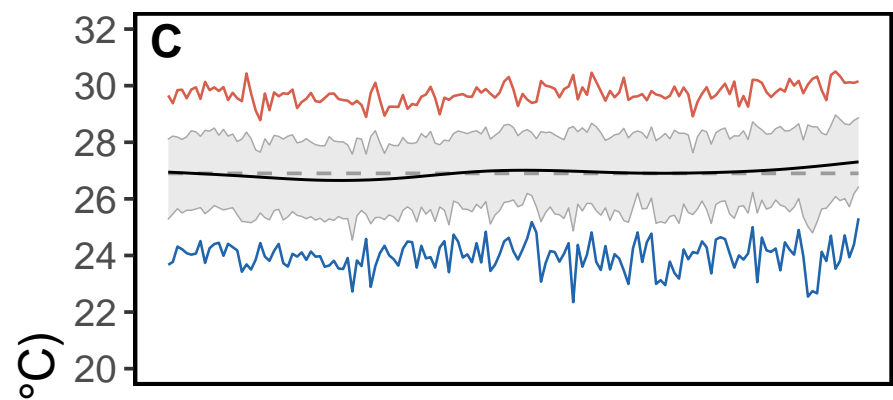

占 3

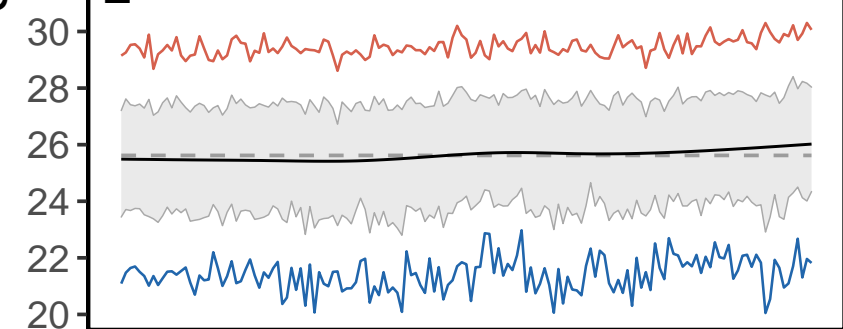

Southwestern Caribbean

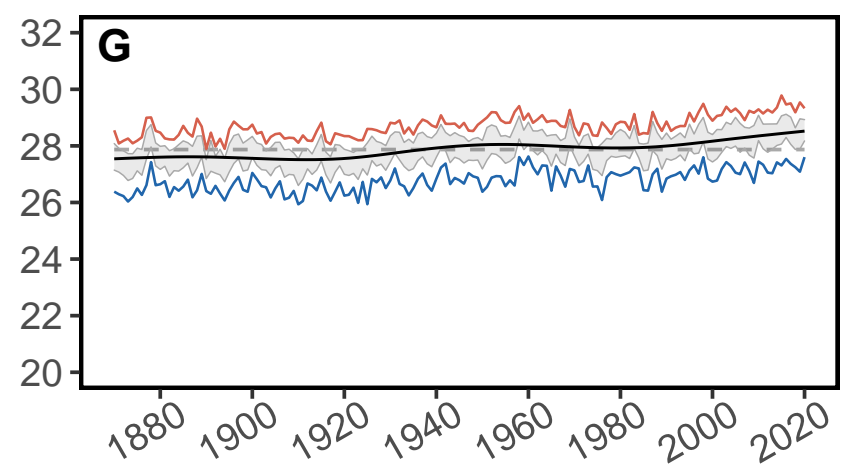

Eastern Caribbean

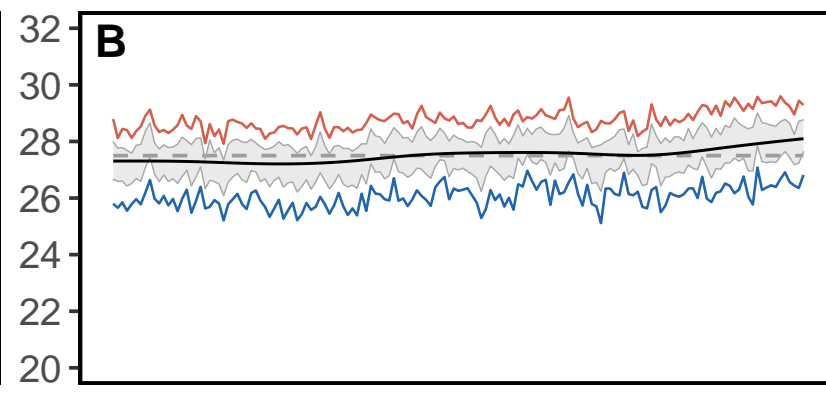

Greater Antilles

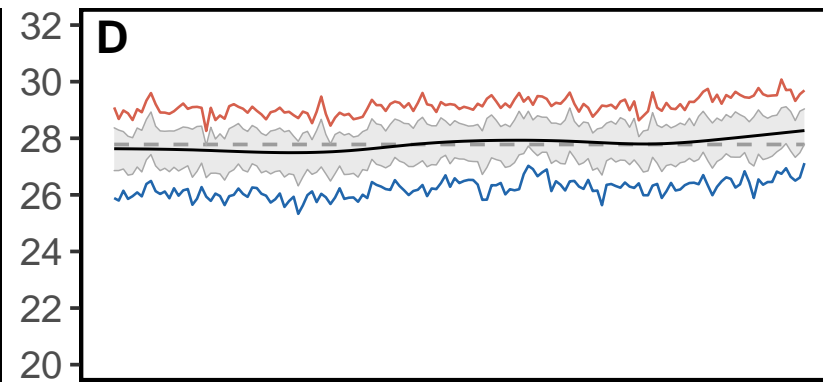

Southern Caribbean

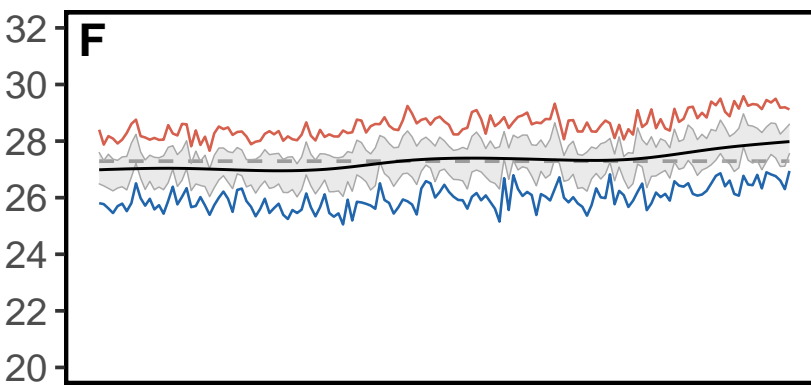

Western Caribbean

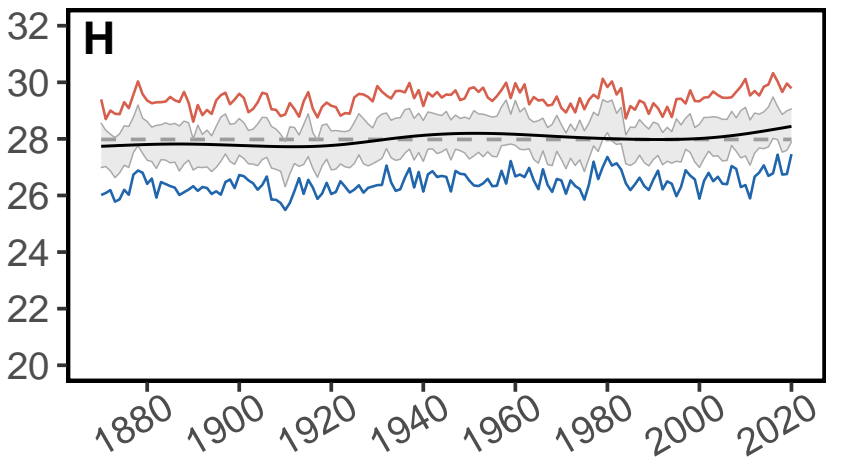


A $\quad$ Caribbean warming rate $(1981-2019)$

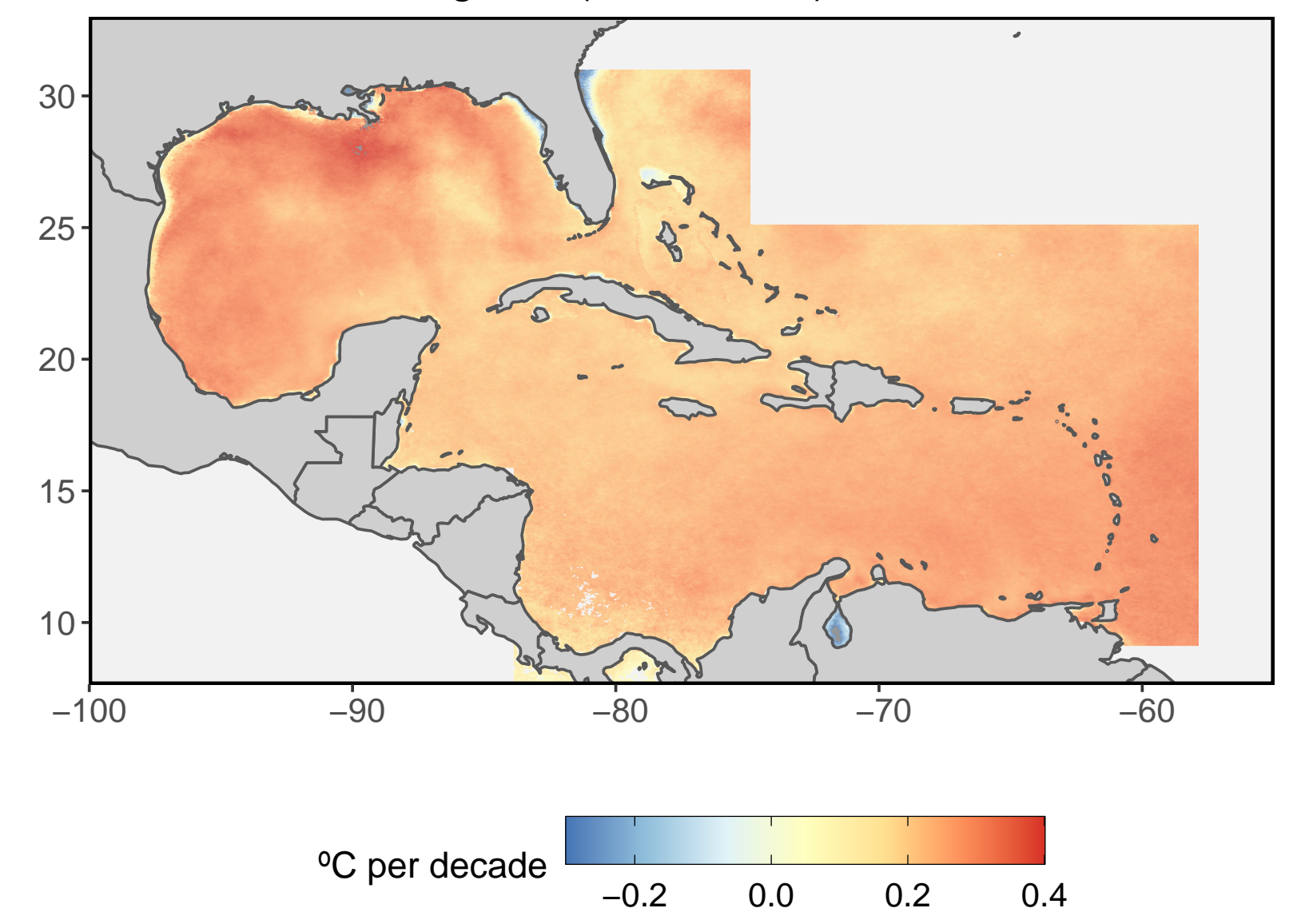

B $\quad$ Change in marine heat wave frequency $(1981-2018)$

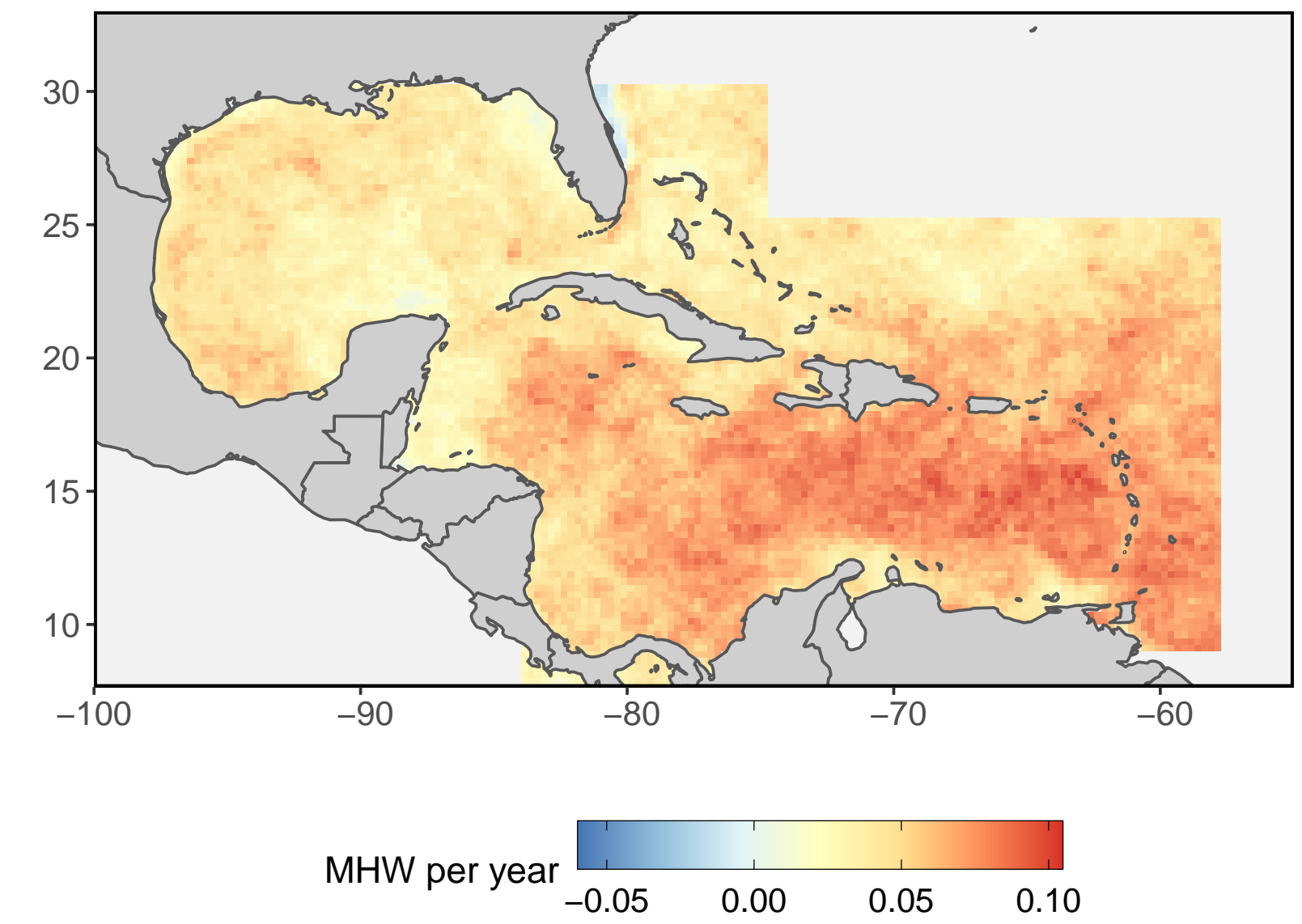



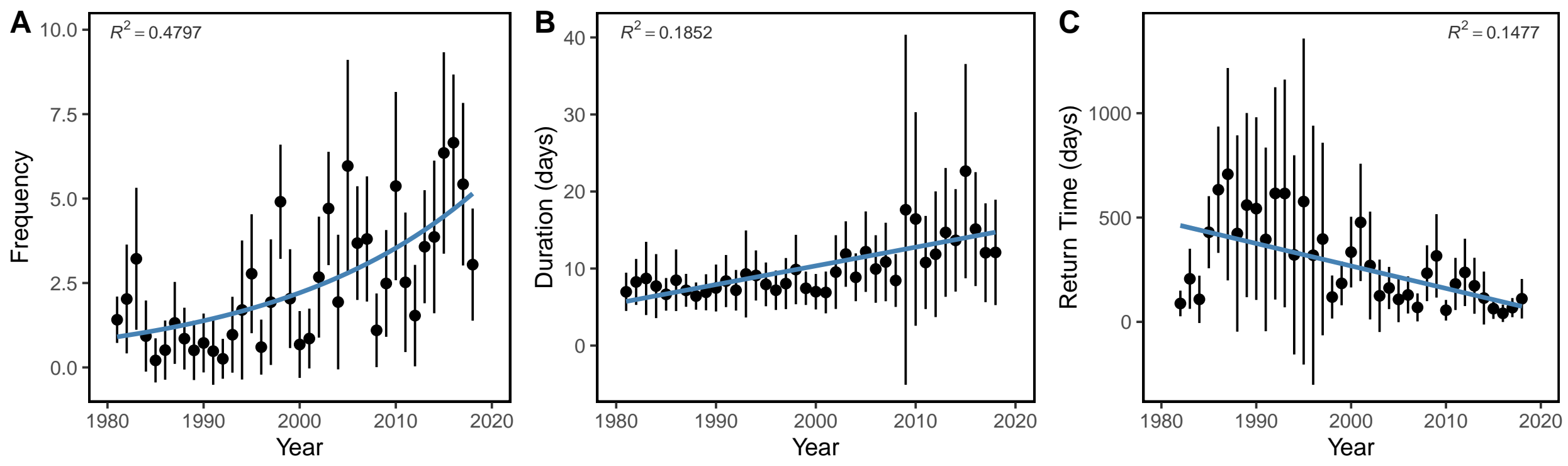